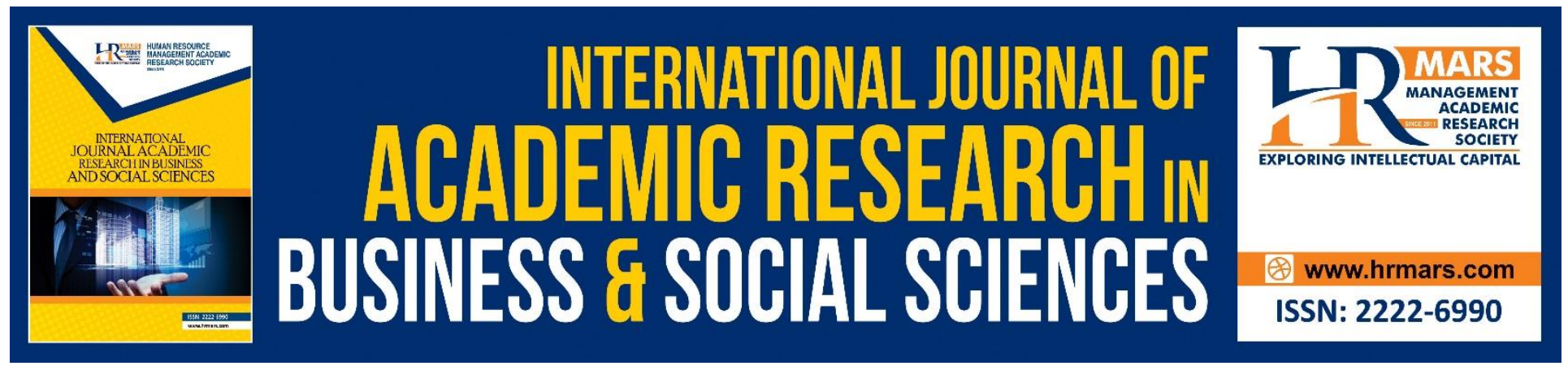

\title{
Assessment of Database of Malaysian Poor Household Record System (E-Kasih), Implication on Poverty Eradication Programme (1 Azam Programme)
}

Radieah Mohd Nor, Narimah Samat, Wan Norhaniza Wan Hasan

To Link this Article: http://dx.doi.org/10.6007/IJARBSS/v9-i2/5612 DOI: $10.6007 /$ IJARBSS/v9-i2/5612

Received: 04 Feb 2019, Revised: 27 Feb 2019, Accepted: 06 March 2019

Published Online: 17 March 2019

In-Text Citation: (Nor, Samat, \& Hasan, 2019)

To Cite this Article: Nor, R. M., Samat, N., \& Hasan, W. N. W. (2019). Assessment of Database of Malaysian Poor Household Record System (E-Kasih), Implication on Poverty Eradication Programme (1Azam Programme). International Journal of Academic Research in Business and Social Sciences, 9(2), 749-761.

Copyright: (c) 2019 The Author(s)

Published by Human Resource Management Academic Research Society (www.hrmars.com)

This article is published under the Creative Commons Attribution (CC BY 4.0) license. Anyone may reproduce, distribute, translate and create derivative works of this article (for both commercial and non-commercial purposes), subject to full attribution to the original publication and authors. The full terms of this license may be seen at: http://creativecommons.org/licences/by/4.0/legalcode

Vol. 9, No. 2, 2019, Pg. 749 - 761

http://hrmars.com/index.php/pages/detail/IJARBSS

JOURNAL HOMEPAGE

Full Terms \& Conditions of access and use can be found at http://hrmars.com/index.php/pages/detail/publication-ethics 


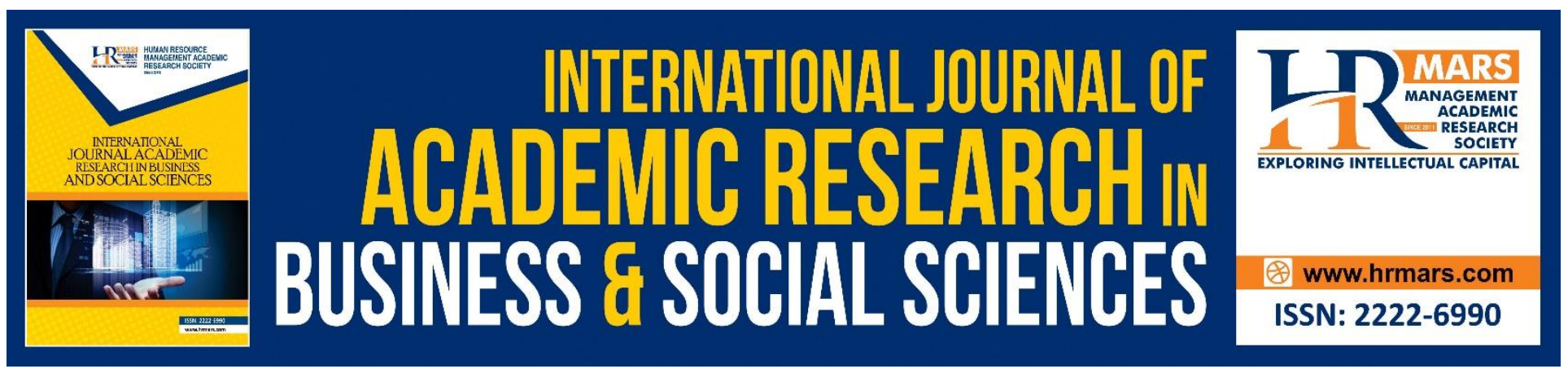

\title{
Assessment of Database of Malaysian Poor Household Record System (E-Kasih), Implication on Poverty Eradication Programme (1 Azam Programme)
}

\author{
Radieah Mohd Nor \\ Centre For Global Sustainable Studies (CGSS), Level 5, Hamzah Sendut Library, Universiti Sains \\ Malaysia, Pulau Pinang, Malaysia \\ Narimah Samat \\ School of Humanities, Universiti Sains Malaysia, Pulau Pinang, Malaysia
}

\section{Wan Norhaniza Wan Hasan}

Centre for Islamic Development Management Studies (ISDEV), Universiti Sains Malaysia, Pulau

Pinang, Malaysia

\begin{abstract}
This study aims to evaluate the database system of record of Malaysia's poor households, known as e-Kasih. Content analysis was performed on 100 participants selected from 11,963 participants. Interviews were conducted with these participants to check the accuracy of data recorded in the eKasih system. Interviews were also held with the Distribution Section, Economic Planning Unit and Implementation Coordination Unit (ICU), Welfare Division of the Prime Minister's Department. This study found that some names of the participants have been repeated many times in the system. In addition, the current monitoring system did not use poverty line income. The results of the interview also found that information recorded are not accurate. On the whole, the e-Kasih system has a good potential to help the poverty groups escape from poverty. The system can also avoid the dumping of aid provided by various agencies on a specific participant at the same time.
\end{abstract}

Keywords: e-Kasih, Poverty, Malaysia, 1AZAM

Introduction

Poverty is said to be a social disease that is difficult to handle. It has been a problem that cannot be solved since the Second World War. The problem of poverty has been prevalent in most countries, especially in low income countries such as Somalia, Tanzania, and Mali (World Bank, 2017). 
Based on the statistics from World Bank (2016), in the year 2013, it was estimated that $10.7 \%$ of the world population lives on less than USD1.90 per day, compared with $12.4 \%$ in 2012 . This means that in 2013, the world population living on less than USD1.90 per day was 767 million people, while in 2012, it was 881 million people. According to the World Bank (2016), half of them are living in SubSaharan Africa, while the rest are living in East Asia and in the Pacific countries, such as China, Indonesia, and South Asia, including India.

However, Malaysian statistics proudly shows that there is a reduction in the poverty rate in Malaysia. Malaysia has successfully reduced its poverty rate from 49.3\% in 1970 to $0.6 \%$ in 2014 (EPU, 2017a). In Sudan the situation is very different. According to Abdelatti et. al. (2016), Malaysia and Sudan have many things in common. Previously, during after independence, Malaysia was focusing on the agriculture sector and then later switched to services and petroleum mining, just as the case in Sudan. Sudan has 16 states while Malaysia has 14 states. Both countries were under the British colony, and indirectly inherited similar type of government and culture from Western colonization. Sudan achieved its independence in 1956, while Malaysia achieved independence a year later, in 1957. In 1970, Malaysia has experienced a conflict resulting in the separation of Singapore from Malaysia. Similarly, in Sudan, South Sudan later separated from Sudan in 2011 (Abdelatti et.al., 2016).

Even though Sudan shares many similarities with Malaysia, Sudan was well ahead in implementing its action plan to strengthen its economy, while simultaneously, eradicating poverty in the country. During 1946 to 1951, and later from 1951 to 1956, Sudan was ahead in implementing its development policy, while it is still under British rule. Under the colonial rule, its development policy, known as the Gezira Scheme aimed to upgrade its transport and communication system. Malaysia began somewhat later, in 1956, with its First Malayan Five-Year Plan (1956-1960). The development of both countries continues until today and the aims are still the same, to develop the people's socioeconomy while simultaneously eradicating poverty in their respective countries (Abdelatti et.al., 2016).

Even though Malaysia started a bit late in its development policy, its development plan proved successful in eradicating poverty. This was shown in the record that the incidence of poverty was at $0.6 \%$ in 2014, whereas in 1970 it was $49.3 \%$ (EPU, 2017a). The situation in Sudan was far different; as shown by the statistics in 2009, 46.5\% of its households were still living under poverty (CBS, 2009).

Like Sudan, Malaysia has its own development policy and plan. The First Malaya Plan aimed to eradicate poverty because the economic inequality between the Malays and other ethnics were too wide. The First Malaya Plan focused on rural development with the aim of correcting the imbalance in the economy of the total population of Malaysia, known as the Malay States at that time. To achieve this aim, two government agencies were formed, namely the Rural Development Industrial Authority (RIDA) and Federal Land Development Authority (FELDA) (FELDA, 2014; MARA, 2017).

However, the First Malaya Plan did not achieve visible encouraging results in handling the problem of poverty. This has resulted in a racial riot in 1969, known as "the 13 May incident." Following the incident, the government introduced the New Economic Policy (NEP), which was implemented as a two-pronged strategy, to restructure the society and to eradicate poverty (Nor et.al., 2015). The New Economic Policy proved successful, hence the same objectives were continued in the national policies such as in the National Development Policy 1991- 2000 (DPN) and in the 
National Vision Policy 2001 - 2010 (DWN). Both these policies were based on the Vision 2020 policy, which constituted the Malaysian target to achieve the status of a developed nation towards year 2020. The Vision 2020 policy was revised and updated with development plans such as the ensuing Malaysia Plans, the New Economic Model and the Economic Transformation programme (ETP) (EPU, 2017b).

This has caused the Malaysian government to widen the scope to cover the $40 \%$ lowest income group in the country. This is also known as the B40, which refers to households earning $\mathrm{RM} 3,860.00$ and less. The aim was to handle the problem of the increasing cost of living that is exerting a heavy pressure on the B40 group (Fairul, 2017).

Malaysia started actively to eradicate poverty among its citizens through the NEP. Even though poverty eradication programmes have been undertaken a year before independence, through FELDA and RIDA, these efforts have been intensified under the NEP through FELDA with land explorations given to requiring citizens. Through these land explorations, they worked mainly on cash crops such as rubber and oil palm. Through these efforts, many of the country's citizens managed to escape from the poverty group. This is proven by the following Table 1.

Table 1: Insider Malaysian Poverty, 1970 -2014

\begin{tabular}{lc}
\hline Year & $\begin{array}{c}\text { Poverty rate } \\
\text { (\%) }\end{array}$ \\
\hline 1970 & 49.3 \\
1976 & 37.7 \\
1979 & 37.4 \\
1984 & 20.7 \\
1987 & 19.4 \\
1989 & 16.5 \\
1992 & 12.4 \\
1995 & 8.7 \\
1997 & 6.1 \\
1999 & 8.5 \\
2002 & 6.0 \\
2004 & 5.7 \\
2007 & 3.6 \\
2009 & 3.8 \\
2012 & 1.7 \\
2014 & 0.6 \\
\hline
\end{tabular}

However, forest areas that can be explored for opening up of settlements and for cash crops are limited, thus the opening of land for planting cash crop and for settlements did not occur. So, the Malaysian government switched its direction from land exploration towards helping the poor citizens by providing them with capital in the form of money and tools as well as skills, which they require to help them get out from poverty. This programme is known as 1AZAM programme and was launched in the year 2010 (Auditor General, 20160). The programme was managed by the Ministry of Women, 
INTERNATIONAL JOURNAL OF ACADEMIC RESEARCH IN BUSINESS AND SOCIAL SCIENCES

Vol. 9, No. 2, Feb, 2019, E-ISSN: $2222-6990$ ๑ 2019 HRMARS

Family and Community Development (KPWKM) as the anchor ministry of the programme, assisted by other institutes organizations such as Ministry of rural and Regional Development, Amanah Ikhtiar Malaysia (AIM) Agriculture Department, and Fisheries Department (Auditor General, 2016).

\section{Data Bank on Citizen Poverty}

To enhance the management of poverty in Malaysia the government has introduced e-Kasih, which is a National Poverty Data Bank; e-Kasih system is a database on poor families, created at the national level to help in the planning, the implementation and the monitoring of poverty programmes implemented by various government agencies involved. E-Kasih was developed following the outcomes of the Meeting of the Ministerial Council on 31 October 2007 and Menteri Besar and Chief Ministers Meeting on 1 November. From the outcomes of these meetings, the system was developed in-house by the Implementation Coordination Unit (ICU) in the Prime Minister's Department (JPM) and put to effect on June 2008 (PPPN, Perak, 2015).

Data keyed in into the e-Kasih system were based on a Poor Household Census or Bancian Isi Rumah Miskin (BIRM). BIRM is a programme approach that looks at the poverty status of households rather than that of individuals. The census was undertaken by Department of Statistics Malaysia (DOS) and handed to ICU JPM, as the main input to e-Kasih (PPPN Perak, 2015).

BIRM was undertaken based in two phases. BIRM 1 was conducted at an overall level, at the rural areas and town areas beginning on December 2007 until June 2008. In this phase, the survey was conducted on areas with pockets of poverty. However, there were areas not included in the pockets of poverty. These areas were areas of Orang Asli (Aborigine Community) settlements, FELDA Settlements, and Estates and plantations because these areas have their own administrative systems. To enhance the e-Kasih system, its second phase was conducted with the keying in of data obtained at the Member of Parliament level or State Legislative Council and state agencies level. The open registration allowed by the e-Kasih was also a data source that contributes data to the e-Kasih. Confirmation of information was done on site and must comply with the e-Kasih criteria, to qualify to be enrolled into the system (PPPN Perak, 2015). In the e-Kasih system, information on poverty starts from individual profile, the programme or aid received by household head (KIR) and Household members (AIR) were all recorded in the system (e-Kasih, 216), This system was developed to facilitate the responsible authorities to obtain information regarding the poor population in Malaysia, in their effort to increase the income of the poverty group, to enable them achieve the status of the middle class income group as stated in the Eleventh Malaysia Plan (RMK11, 2015).

This integrated data system manages the provision of aid or programme by the government so that they are distributed equitably, by avoiding overlap in the distribution of aid to the recipients and monitoring the effectiveness of efforts of increasing the economic status of poor households. This system was launched in 2007 and has emerged the winner for the United Nation Public Service Award (UNPSA), under the category of Enhancing Management of Information in Government for the Asia Pacific Region, in New York in 2012 (The Star Online, 2012; Sinar Online, 2012).

Even though Malaysia has won the UNPSA award, Malaysia is not the only country that has a data bank related to its poor population. On the other hand, the Philippines, Indonesia, China, Ghana, and Cambodia also have data bank such as the one that Malaysia has. 
The Philippines has introduced an information management system called The National Household Targeting System for Poverty Reduction (NHTS-PR). This database serves to identify the existence and the location of poverty areas. The Philippines government used this database as a guide to provide the needy people the form of aid or programme according to their priorities. It also identifies the qualified aid recipients, especially in the provision of Conditional Cash Transfer (CCT) programme in a more efficient and effective way (JICA, 2012). The NHTS-PR system has benefitted almost 3.8 million poor households in the CCT scheme (Gevere, 2011). The NHTS-PR system is also supported by the Family Income and Expenditure (FIES) and Small Area Estimates (SAEs) in enhancing the NHTS-PR database (Open Data Philippines, 2017). In addition, in the poverty eradication efforts, the Philippines has brought forward a framework for poverty management called Kapit-Bisig Laban sa Kahirapan (KALAHI) to reduce the poverty rate, to improve the welfare of the society and to empower them. The antipoverty agenda of the KALAHI framework comprises some main strategies, among which are accelerating the renewal of assets, programme for basic services, job creation and micro-financing services, provision of protection to the hard core and vulnerable poverty groups, to empower the poor and the isolated groups as well as building infrastructures to help the poor groups (Arroyo, n.d.).

Indonesia has also introduced The Unified Data Base for Social Protection Programmes (UDB) which contains detailed information sources concerning the socio-economic status of the largest number of households in the world totalling to 25 million households. Similar to other integrated systems, the UDB serves to ensure the accuracy and the effectiveness the dissemination of aid, which is also combined with a method of mapping poverty such as the one used in the NHTS-PR in the Philippines. Prior to the introduction of the UDB, the dissemination of aid or programmes to poor households was based on information gathered by various ministries separately. The introduction of the UDB, has enabled all information to be gathered in a single data base and an integrated approach that can be used to target, through specific programmes based on the appropriate criteria. Among the programmes involving the use of UDB is

(a) Rice subsidy programme for the poor (Raskin), a subsidised rice aid to low-income households,

(b) Program Keluarga Harapan (PKH), involving cash to very poor households (RTSM); also known as Conditional Cash aid,

(c) Aid Programme to poor students (PBSM), which aims to increase the education level of underprivileged students, and

(d) Community Health Assurance (Jamkemas) which aims to enhance the access of the poor community to overall health (TNP2, 2017).

These programmes improved through the implementation of UDB, and they became more effective compared with previously, when they were implemented without using data from UDB (Bah et al., 2015).

In 2006, Cambodia introduced an integrated data system known as the Identification of Poor Households (IDPoor) Programme (IDPoor, 2005). The system provides updated information every two years and allows government and non-government agencies to access them for ensuring the aid programmes to the poor and vulnerable population can be distributed and accurately targeted through the use of the database provided. Expediency of acceptance for technical aid was identified 
based on three different groups based on economic indicators such as First Stage (very poor), Second Stage (poor), Third Stage (Not Poor) apart from additional non-economic indicators that are also taken into consideration (Tsuruga, 2010). The identification system is similar to the e-Kasih system in Malaysia. Under IDPoor, some forms of aid or programmes are provided such as free medical services, educational scholarships, tuition-fee waiver, agriculture-based services and training, social land concession allocation, free food and basic needs distribution and other programmes implemented. Up till 2017, IDPoor has covered the whole of 25 regions in Cambodia (IDPoor, 2015).

Ghana also has its own database, just as in other countries as has been explained. Ghana has a system known as Ghana National Household Registry (GNHR). Just as in the other systems already explained, GNHR also has the objectives of facilitating its agencies to distribute aid accurately, fairly and equitably. Additionally, it also helps the government of Ghana to distribute aid and avoid duplication. Through GNHR, socio-economic development can be analysed accurately to support development plans and programmes, especially for the low-income and vulnerable groups (GNHR, 2016).

The National Poverty Monitoring System (NPMS) introduced in China is quite different than those already explained. This system concentrates more on the urban poor only. Through the NPMS, reports are handed to the government and used as the main reference for the government to determine the poverty line, the size of the poor population, and factors causing poverty. This system also helps the government, non-government organisations (NGOs) and international organizations to execute programmes for the poor groups (Xian, n.d.).

\section{Methodology of the Study}

The present study was conducted to evaluate the data on poor population contained in the e-Kasih system. The accuracy of the data in the e-Kasih database will be checked. For that purpose, data on the participants of 1AZAM programme will be studied to check for the accuracy of the records listed under the e-Kasih, which is being studied. The 1AZAM programme was selected as the sample of the study because the participants were selected based on the list of poor population listed in the e-Kasih. Data on the 1AZAM participants were obtained from Division of People's Welfare, ICU, JPM.

Before a participant of 1AZAM is confirmed as a recipient, the participant has to go through some vetting processes. The vetting processes do not only involve information in the forms submitted by the participants, but vetting was also done through interviews and home visits to ensure the participants who received the aid are truly entitled to receive the aid (Auditor General, 2016).

Based on the data obtained from ICU JPM, 100 questionnaires have been used to conduct interviews randomly in three states in Peninsular Malaysia, namely in Penang, Kedah and Perlis. All these questionnaires involve participants enlisted in the e-Kasih system who received 1AZAM aid. 


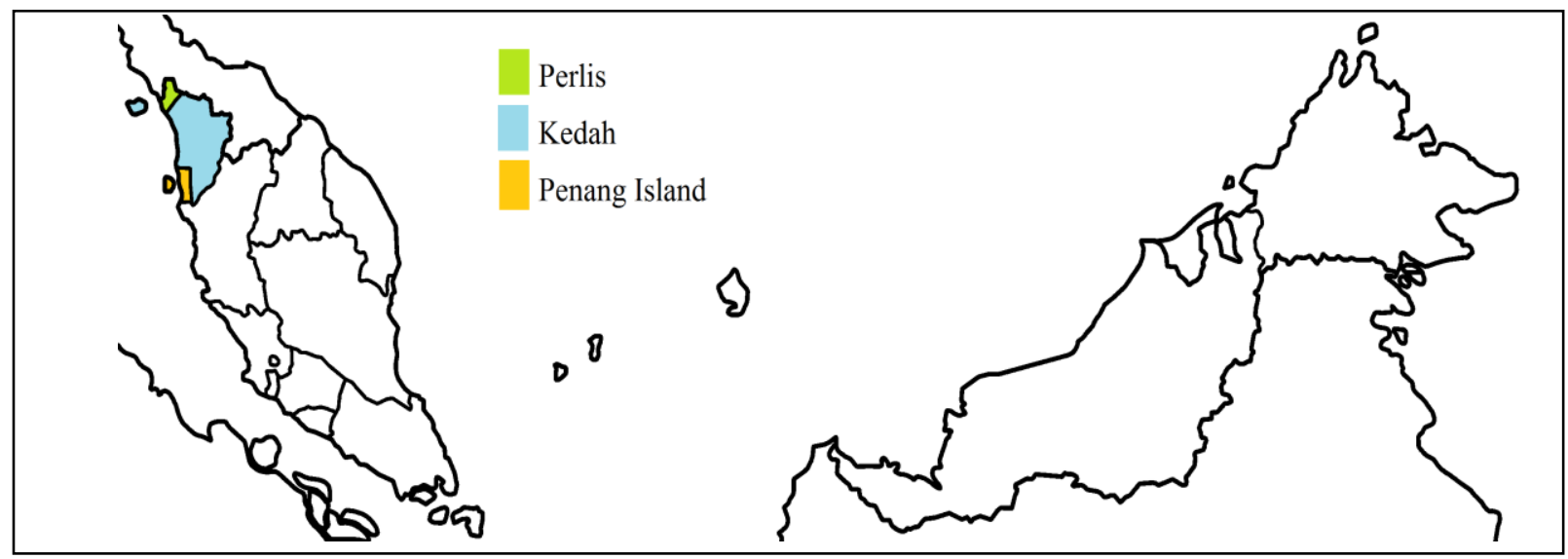

Figure 1: Location of respondents in the northern region of Malaysia, namelv Perlis, Kedah and Penang Island

In addition, interviews were also conducted with the Distribution Section of the EPU and Division of People's Welfare, ICU, JPM to gather more detailed information about the relationship between IAZAM and e-Kasih. The data were further analysed using content analysis to understand the questions and issues emerging from the e-Kasih system database.

\section{Research Findings}

\section{Repetition in Names of Participants}

Data of 1AZAM participants obtained in the form of Microsoft Excel from the Division of Welfare, ICU, JPM were found to contain many repetitions, with the names and identity card numbers of participants. Some names were repeated twice to six times. The examples of the occurrence of such overlaps are shown in Table 2. However, the names, IC numbers, and telephone numbers listed here have been changed from the original data. 
INTERNATIONAL JOURNAL OF ACADEMIC RESEARCH IN BUSINESS AND SOCIAL SCIENCES Vol. 9, No. 2, Feb, 2019, E-ISSN: $2222-6990$ ๑ 2019 HRMARS

Table 2: The examples of the occurrence of such overlaps from Data of 1AZAM participants

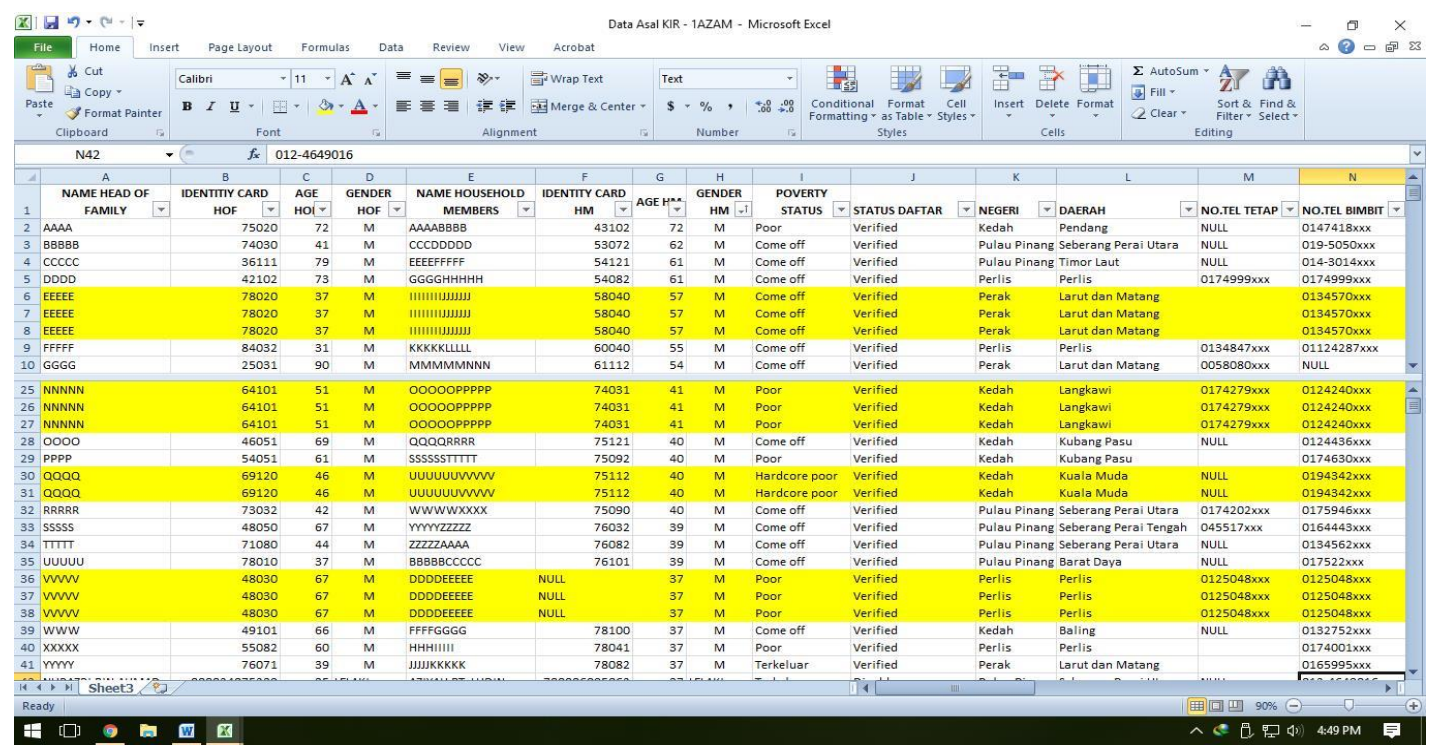

Therefore, repeated names were removed from the data. After all the repetitions were removed, 11,963 names were left. Originally, the data contained 21,736 names. This means that $45 \%$ of the names in original list have been repeated or are overlapped.

Such overlaps should not have occurred in the e-Kasih system. This would make it difficult for the responsible authorities to perform their tasks, especially in empowering the poverty group listed in the system. To avoid duplication of names and assistance received, the biometric system in identity card owned by every citizen can be utilized maximally so access to information not only through the existing e-Kasih system but also through identity cards by recording all information participants and assistance received in the biometric system.

\section{Reviewing the status of the participants}

The data obtained from the Division of Welfare ICU, JPM, showed that 11,963 participants have been listed in the e-Kasih system that has been approved to receive various forms of aid under the 1AZAM programme. The record on the status of 1AZAM participants is shown in Table 3.

Table 3: The Total Number of Aid Recipients of 1AZAM as of September 2015

\begin{tabular}{lc}
\hline \multicolumn{1}{c}{ Participants' status } & Number \\
\hline Poor & 3,309 \\
Hard core poor & 634 \\
Vulnerable poor & 16 \\
Escaped poverty & 7,394 \\
No information & 610 \\
\hline Total participants & $\mathbf{1 1 , 9 6 3}$ \\
\hline
\end{tabular}


Interestingly, the implementation of the 1AZAM has specified that success happens when a participant is able to increase his or her income by RM300 in any three months of the year (PEMANDU, 2015). This specification is very different from concept of Malaysia's poverty line income (PGK) that specifies an income of RM950 for Malaysia. The PGK is an income level that is used to measure absolute poverty based on minimum food requirements, but not food required by members of a household to achieve a healthy and active life (EPU, 2015).

The inconsistency between the success line determined in the 1AZAM system and the national PGK can create many problems, especially when 1,162 participants are listed as having escaped the poverty status while their incomes are still below the PGK. However, the others 6,232 participants (84\%) have recorded incomes higher than the PGK. The total participants who are still earning below the PGK are 3,801 (31\%), while the rest 8,162 participants (68.2\%) are earning above the PGK.

The poverty eradication programmes implemented by the government should be in line with the report produced at the national level. On the contrary, it is unfortunate that when the 1AZAM programme was implemented it fixed the measurement of success in the 1AZAM programme lower than the PGK. It would be problematic for the government to help the poverty group because the government would most probably need to create another poverty programme to ensure the monthly incomes of the poverty group rise above the PGK. Therefore, it is important that the success line that has been determined in the 1AZAM programme be in line with the national PGK, such that the implication of success is translated correctly in accordance with the PGK and national statistics on Malaysian poverty.

\section{Inaccurate Participant Information}

Based on the telephone interviews conducted on 100 1AZAM participants in Penang, only 82 of them could be contacted. The other 18 participants could not be contacted because their contact number listed in the e-Kasih system belonged to some other persons and their numbers were not registered online. From the 82 participants contacted, 47 of them have received the aid they applied for. However, another 25 have not received their aid, while another 10 of them mentioned that they have never registered in the e-Kasih, in fact they did not even know about the existence of the 1AZAM aid programme.

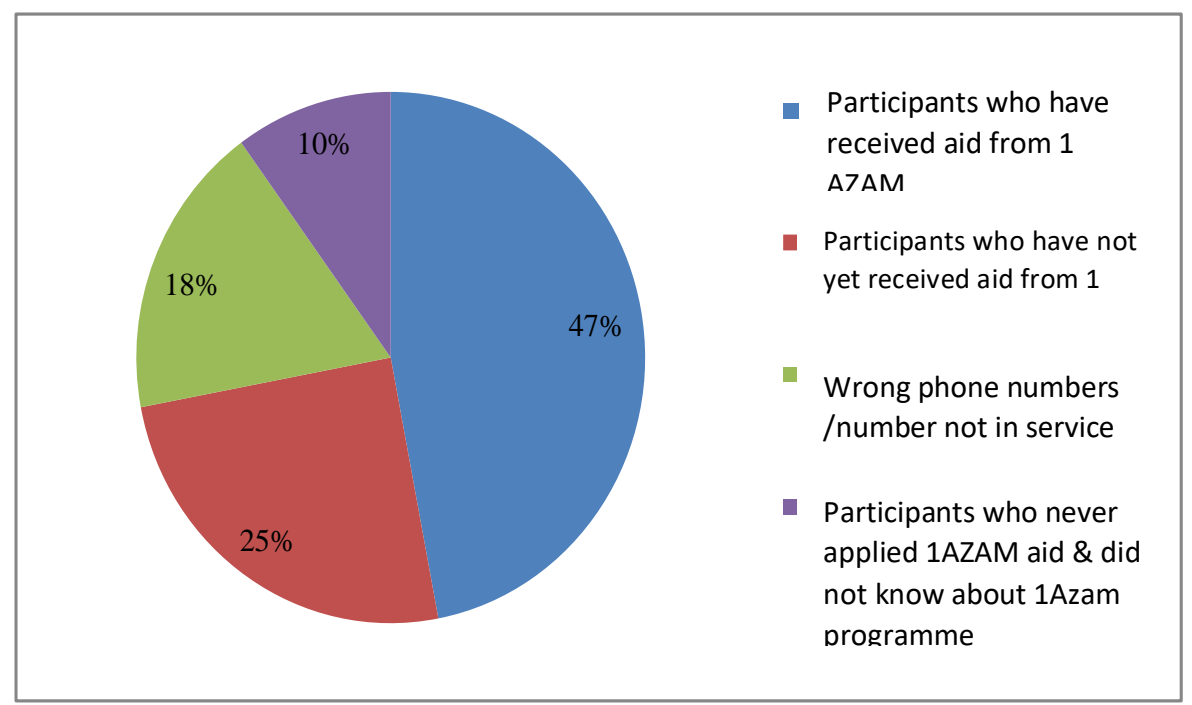

Figure 2: Chart showing results of interviews with 1 AZAM programme participants 
Such findings are quite surprising, especially when 10 participants or $10 \%$ of the interviews conducted have never applied for aid, yet their names were found in the list of applicants. This implies that their personal information was used without their permission. Their information was channelled by a third party with the hope of helping them obtain benefits from the 1AZAM programmes, while they did not know about it. This can endanger their security if this information is used by a third party without their permission and they did not know about it. If this information falls into the wrong hands, various crimes and other wrong doings can occur.

In addition, $18 \%$ of the total interviews showed that they have changed the telephone numbers. This means that these participants can no longer be contacted through online telephone by the officers. Instead, the officers have to go to their houses to know their development. The telecommunication system in Malaysia is a good system of communication, which covers almost the whole nation. However, some forms of control on the changing or purchasing of new numbers should be enforced so that these numbers are not easily changed unpredictably and could be misused by irresponsible individuals.

Out of the total number of participants interviewed, $25 \%$ of them have not yet received the aid they have applied for even though six months have elapsed. The lateness in receiving aid is because the applicants have to go through a detailed vetting process for the government to ensure they truly deserve to receive the aid applied for. However, the approval period need to be shortened to at least three months to allow the applicants escape poverty as quick as possible.

\section{Conclusion}

A presentation in Parliament by the Ministry of Women, Family and Community Development showed that the Ministry is looking very seriously at every leakage that is occurring. The interview held with the EPU also showed that presently they are putting all efforts to improve the problems involving the e-Kasih system and every leakage that is occurring in the 1AZAM programme. Small as it looks, on the whole, the problems can have big implications to the smooth implementation of the poverty eradication programme in Malaysia.

The content analysis of secondary data and telephone calls found that there were some problems in e-Kasih data and the 1AZAM Program. The problems that exist in the data are the repertoire of the names of repeat participants for more than one support from the government, participants cannot be contacted via telephone lines, participants do not know their names listed in the 1AZAM Program, and participants have not received any support has long been registered in the program. This situation will cause problems in distributing aid to the poor. Better data management is needed to address such problems so that government-provided assistance can really be utilized by the participants thus removing the poor from the chains of poverty. In addition, in order to avoid duplication of names and assistance received, the biometric system in identity card or MyKad owned by every citizen can be utilized maximally so access to information not only through the existing eKasih system but also through identity cards by recording all information participants and assistance received in the biometric system.

The e-Kasih system is a good system and can help the stakeholders to implement good poverty eradication programmes with the available data accumulated. However, this system cannot help the stakeholders to perform their task well if the available data do not reflect the actual 
INTERNATIONAL JOURNAL OF ACADEMIC RESEARCH IN BUSINESS AND SOCIAL SCIENCES

Vol. 9, No. 2, Feb, 2019, E-ISSN: 2222-6990 C 2019 HRMARS

situation. Therefore, accurate data are urgently required to allow the programmes of poverty eradication to be successfully implemented.

\section{ACKNOWLEDGEMENT}

This paper is a part of a research funded by Research University Grant (1001/PCGSS/816308) awarded by Universiti Sains Malaysia. The writers wish to express their heartiest gratitude to all other parties who have been involved either directly or indirectly in this research.

\section{REFERENCES}

Auditor General (2016) Laporan Jawatankuasa Kira-kira Wang Negara (PAC) Parlimen Berhubung Pengurusan Program 1AZAM oleh Kementerian Pembangunan Wanita, Keluarga dan Masyarakat. Kuala Lumpur: Dewan Rakyat Ketiga Belas Penggal Keempat.

Bah, A., Nazara, S. and Satriawan, E. (2015) Indonesia's Single Registry for Social Protection Programmes, The International Policy Centre for Inclusive Growth. Retrieved from http://www.ipcundp.org/pub/eng/PRB49_Indonesia_s_Single_Registry_for_Social_Protection_Programmes .pdf

CBS, Central Bureau of Statistics (2009) Sudan National Baseline Household Survey 2009: North Sudan - Tabulation Repot. CBS: Khatrtoum.

eKasih, Portal Pembasmian Kemiskinan (2016) Info eKasih. Retrieved from https://ekasih.icu.gov.my/Pages/InfoeKasih.aspx

EPU, Economic Planning Unit (2015) Rancangan Malaysia Kesebelas. Putrajaya: The Prime Minister's Department of Malaysia.

EPU, Economic Planning Unit (2017a) Household Income \& Poverty. Retrieved from http://www.epu.gov.my/en/socio-economic/household-income-poverty24

EPU, Economic Planning Unit (2017b) Development Plans. Retrieved from http://www.epu.gov.my/en/development-plans/previous-plans

Fairul, F. A. (2017, January 25) Personal Interview.

GNHR, Ghana National Household Registry (2016) The Ghana National Household Registry. Retrieved from http://gnhr.gov.gh/about-gnhr/objectives

IDPoor, The Identification of Poor Households Programme (2015). The Identification of Poor Households Programme. Retrieved from http://www.idpoor.gov.kh/en/home/1/1

MARA, Majlis Amanah Rakyat (2017) Introduction \& History. Retrieved from http://www.mara.gov.my/en/pengenalan-sejarah

MStar (2015) Kegagalan 1Azam, PAC panggil dua individu. Retrieved from http://www.mstar.com.my/berita/berita-semasa/2015/03/24/pac-

1azam/\#IbqVc2KbLGTf3jrp.99 
INTERNATIONAL JOURNAL OF ACADEMIC RESEARCH IN BUSINESS AND SOCIAL SCIENCES

Vol. 9, No. 2, Feb, 2019, E-ISSN: 2222-6990 C 2019 HRMARS

Nor, R., Azhar, S. and Ibrahim, K. (2015). Population Restructuring: The Impact on Poverty Eradication in Malaysia and Medina. Open Journal of Social Sciences, Vol.3, 65-79.

PEMANDU, Unit Pengurusan Prestasi dan Pelaksana (2015) Laporan Tahunan Program Transformasi Kerajaan 2014. Putrajaya: Jabatan Perdana Menteri.

PPPN Perak, Pejabat Pembangunan Persekutuan Negeri Perak (2015). FAQ Permohonan Bantuan EKasih. Retrieved from http://www.prk.icu.gov.my/v3/index.php/layout1/252

Sinar Online (2012, Jun 26) eKasih menang Anugerah Perkhidmatan Awam PBB 2012, http://www.sinarharian.com.my/nasional/ekasih-menang-anugerah-perkhidmatan-awampbb-2012-1.61049?localLinksEnabled=false

The Star Online (2012, Jun 29) Malaysia's eKasih is No. 1, http://www.thestar.com.my/news/nation/2012/06/29/malaysias-ekasih-is-no-1/

TNP2K, Tim Nasional Percepatan Penanggulangan Kemiskinan (2017). Tim Nasional Percepatan Penanggulangan Kemiskinan. Retrieved from http://www.tnp2k.go.id/

Tsuruga, I. (2010) Identification of Poor Households Programme (ID Poor). Retrieved from http://www.povertist.com/identification-of-poor-households-programme-id-poor/

World Bank (2016) Overview. Retrieved from http://www.worldbank.org/en/topic/poverty/overview

World Bank (2017) Low income. Retrieved from http://data.worldbank.org/income-level/lowincome?view=chart 